\title{
High-performance lightweight structures with Fiber Reinforced Thermoplastics and Structured Metal Thin Sheets
}

\author{
Holger Seidlitz ${ }^{1}$, Colin Gerstenberger ${ }^{1}$, Tomasz Osiecki ${ }^{1}$, Sylvio Simon ${ }^{2} \&$ Lothar Kroll $^{1}$ \\ ${ }^{1}$ Institute of Lightweight Structures, Chemnitz University of Technology, Chemnitz, Germany \\ ${ }^{2}$ Professorship of Machine Tools, Brandenburg University of Technology, Senftenberg, Germany \\ Correspondence: Holger Seidlitz, Institute of Lightweight Structures, Chemnitz University of Technology, \\ Chemnitz, Germany. Tel: 49-371-5313-5551. E-mail: holger.seidlitz@mb.tu-chemnitz.de
}

\author{
Received: September 30, 2014 Accepted: October 18, 2014 Online Published: November 24, 2014 \\ doi:10.5539/jmsr.v4n1p28 \\ URL: http://dx.doi.org/10.5539/jmsr.v4n1p28
}

\begin{abstract}
A heavy-duty multi-material-design (MMD) can be realized through the combined use of structured sheet metal and reinforced plastics (FRP). To exploit the high lightweight potential of the various material groups within a multi-material system as efficient as possible, a material-adapted and particularly fiber adjusted joining method must be applied. The present paper primarily focuses on the manufacturing and mechanical testing of novel multi-material joints with structured sheet metals and carbon fiber reinforced thermoplastics (CFRP). For this purpose the applicability of the new Flow Drill Joining (FDJ) method, which was developed for joining of heavy-duty metal/composite hybrids, was investigated.
\end{abstract}

Keywords: multi-material design, fiber reinforced plastics, structured metal thin sheets, joining

\section{Introduction}

Load-path adapted multi material designs initiate significant savings of energy and material in automotive industry. Of all the material groups, the combined use of metal sheets and fiber-reinforced plastic (FRP) offers a very high lightweight potential (Klein, 1997; Rosato, 2005; Goede et al., 2010). With respect to this, metal components are usually applied for a uniform initiation of concentrated loads. In contrast to that FRPs are more suitable for load transmission along large distances (Schürmann, 2005; Kroll, 2009).

In particular, the use of thermoplastic FRPs with high strength and stiffness properties is raised sharply within the last decade in automotive industry (Ind.Exp., 2013; Witten, 2013). Primarily this is due to comparatively short cycle times when manufacturing components and the use of inexpensive matrix systems such as polypropylene, but also higher-quality plastics such as polyamide or polyether ether ketone. Consequently they are predestined for large scale production of complex lightweight structures (Döhler et al., 2014).

The use of structured metal sheets also offers a high lightweight potential for multi-material designs (Sterzing, 2005; Malikova et al., 2013). In Particular three dimensional structured sheets with embossed secondary design elements, vault structures or beadings are characterized by much higher bending stiffness-values than plane sheets. On the one hand this is caused by a higher moment of inertia and on the other by the strain hardening effect, which is evoked by the forming process (Viehweger et al., 2002). Compared to a plane sheet metal construction, the wall thickness can be consequently reduced and ultimately also the component weight.

Through the combined use of thermoplastic FRPs and thin-walled structured metal sheets, weight-optimized components of a body in white can be developed for vehicle construction. For instance the described multi-material approach can contribute to increase the rigidity of a body in white structure while reducing weight. For this the required joining technology takes a central role within the manufacturing process.

The joining of thin-walled structural components, made of FRP and metal sheets, is considered to be an extreme challenge. Usually - due to the strongly different thermo-mechanical behavior and the divergent material composition and morphology - primarily mechanical methods such as screwing, blind and punch riveting as well as hybrid techniques are applicable (Simon, 2005). Regarding this, high and strong local acting joining forces cause a process-related smoothing of the structured cross-section. This reduces the excellent bending stiffness of the thin-walled and structured sheet metal components considerably (Viehweger et al., 2005). 
Furthermore the conventional placing of joining elements leads to a sectioning of load bearing fibers at the load introduction zone of the FRP. As a consequence, high notch stresses are induced, which weaken the FRP component significant and prevent the optimal exploitation of the high anisotropic lightweight potential (Colins, 2006; Seidlitz et al., 2011). Therefore additional reinforcements like cones and patches are applied at critical notch stress areas, which consequently lead to a strong over-sizing of the joint, an increased component weight and most of all space problems. To fully exploit the high anisotropic material behavior of the FRP, the joining process must be performed very gentle as well as load path adapted (Rotheiser, 2009).

This paper focuses on the qualification of the new flow-drill joining (FDJ) concept - against the background of thin walled structured sheets (Seidlitz, 2013a). The technology is currently used to join plane metal sheets and thermoplastic FRPs within wall thickness range of 1.5 to $4.0 \mathrm{~mm}$ (Seidlitz, 2013b). In analogy to constructions in nature, the fibers can be aligned along the force flux lines at the joint of the FRP component. It is possible to achieve high joining strengths in this way. The fiber realigning effect was proven in tensile shear tests on mixed joints with structured steel and aluminum thin sheets as well as orthotropic carbon and glass fiber reinforced FRPs with polyamide 6 (PA6) matrix. Finally the joints were pyrolysed to evaluate the fiber arrangement at the joint.

\section{Method}

\subsection{Specification of Test Materials}

Structured thin sheet metals are mostly produced by rolling (rolled structured sheets), embossing (waffle-type structured sheets), or hydro forming (spherical-type structured sheets). Process-related through the forming process a high level of strain hardening occurs. In addition to the high bending stiffness values, structured thin sheets are characterized by increased heat absorption and vibration stiffness. In comparison to plane sheet metals, this phenomenon is evoked by the larger surface. Therefore they are often used for heat shielding and sound insulation.

In this paper, orthotropic structured steel and aluminum thin sheets are investigated, which are mainly produced in roll forming processes. Table 1 summarizes them and gives an overview referring to mechanical properties, the used alloys, structure pattern, wall thickness and the cross section height.

Table 1. Properties of metallic joining partners

\begin{tabular}{|c|c|c|c|c|c|c|}
\hline material & $\begin{array}{l}\text { young's } \\
\text { modulus }\end{array}$ & $\begin{array}{l}\text { tensile } \\
\text { strength }\end{array}$ & $\begin{array}{l}\text { yield } \\
\text { strength }\end{array}$ & pattern & $\begin{array}{l}\text { cross } \\
\text { section } \\
\text { height }\end{array}$ & thickness \\
\hline $\begin{array}{l}\text { Steel } \\
\text { FeP04 } \\
\text { (DIEDRICHS) }\end{array}$ & $210 \mathrm{GPa}$ & $315 \mathrm{MPa}$ & $176 \mathrm{MPa}$ & & $1.8 \mathrm{~mm}$ & $0.5 \mathrm{~mm}$ \\
\hline $\begin{array}{l}\text { Aluminium } \\
\text { AlMg2.5 } \\
(\mathrm{KMT})\end{array}$ & $73 \mathrm{GPa}$ & $207 \mathrm{MPa}$ & $110 \mathrm{MPa}$ & & $2.4 \mathrm{~mm}$ & $0.5 \mathrm{~mm}$ \\
\hline & & & & 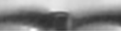 & & \\
\hline
\end{tabular}

Thermoplastic FRP's in the form of so called organic sheets are flat semi-finished products, which can be prepared by stacking of unidirectional (UD) pre-impregnated layers (prepregs) and subsequent pressing in at matrix melting temperature (for polyamide 6: $220^{\circ} \mathrm{C}$ ). Thus thermo formable unidirectional and multidirectional composite structures with defined mechanical properties can be produced within short cycle times. Furthermore, in addition to the high specific strength and stiffness properties, thermoplastic FRP's possess comparatively high damping characteristics, good crash resistance as well as material immanent recycling properties. Subject matter of the 
investigations are FRP's with orthotropic glass and carbon fiber reinforcement, embedded in a polyamide 6 (PA 6) matrix system. Table 2 gives an overview referring to the applied unidirectional (UD) prepreg systems, lamina lay-up and further specific properties.

Table 2. Properties of GFRP and CFRP joining partners

\begin{tabular}{|c|c|c|c|c|c|c|}
\hline FRP type & prepreg & lay up & $\begin{array}{l}\text { young's } \\
\text { modulus } \\
\mathrm{E}_{1}=\mathrm{E}_{2}\end{array}$ & $\begin{array}{l}\text { tensile } \\
\text { strength } \\
\sigma_{1}=\sigma_{2}\end{array}$ & $\begin{array}{l}\text { fiber volume } \\
\text { ratio }\end{array}$ & thickness \\
\hline GFRP & $\begin{array}{l}\text { UD glass } \\
\text { fibre/PA } 6 \\
\text { (Ticona) }\end{array}$ & {$[0 / 90]_{\mathrm{s}}$} & $16.8 \mathrm{GPa}$ & $368 \mathrm{MPa}$ & 0.6 & $1.2 \mathrm{~mm}$ \\
\hline CFRP & $\begin{array}{l}\text { UD carbon } \\
\text { fibre/PA } 6 \\
\text { (Ticona) }\end{array}$ & {$\left[(0 / 90)_{3}\right]_{\mathrm{s}}$} & $49.5 \mathrm{GPa}$ & $860 \mathrm{MPa}$ & 0.6 & $1.6 \mathrm{~mm}$ \\
\hline
\end{tabular}

\subsection{Flow Drill Joining Concept}

The flow drill joining (FDJ) concept, which was developed at the Institute of Lightweight Construction at Chemnitz University of Technology, primarily serves to join comparatively thicker thermoplastic FRPs with metal sheets. The process is characterized by short processing times, high-strength joining properties appropriate for the force fluxes as well as the high degree of lightweight construction and can be utilized in various industrial sectors. The essential advantage towards typical joining technologies relates to the fact that no additional auxiliary joining elements are needed for joining the components.

In order to manufacture a FDJ joint, the plastic flow properties of the metal component are exploited in a targeted way. With the aid of a rotating mandrel, a bushing is thermo-mechanically shaped from the metallic base material. While doing so, this bushing is pushed directly through the also locally plasticized thermoplastic FRP component during the shaping operation and is subsequently pulled over in a positive-locking form when the mandrel is retracted or in an additional working step (Figure 1).

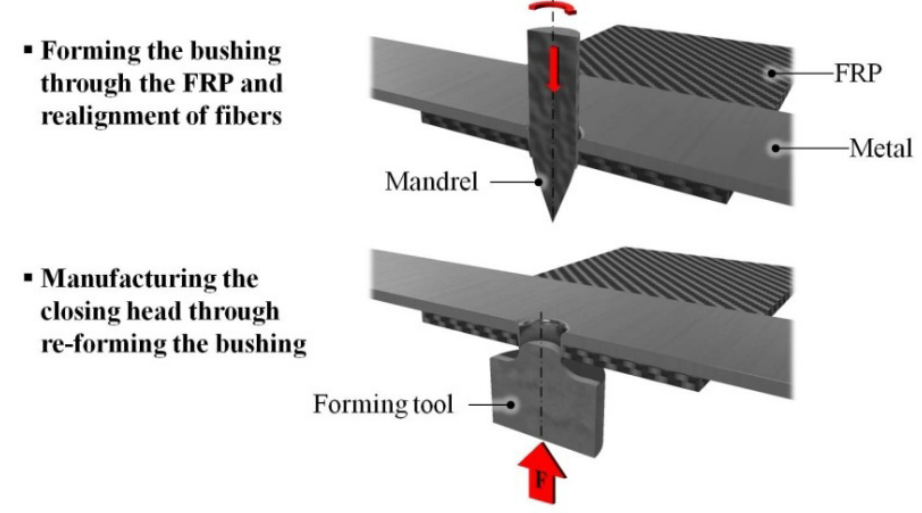

Figure 1. Process scheme for manufacturing FDJ joints

The rotation of the mandrel and the associated friction serve to release thermal energy which is locally introduced into the FRP component as a result of the process and thus initiates the partial melting of the thermoplastic matrix. Therefore, the continuous fibers arranged in the plastic become "moveable" and can be aligned towards the force fluxes during the shaping of the bushing (Figure 2a).

The described FDJ process was carried out by an automated joining jig (Figure 2b). According to DIN EN ISO 14273, the machine serves to manufacture tensile shear test specimens with a length of $175 \mathrm{~mm}$, width of $50 \mathrm{~mm}$ and an overlapping length of $35 \mathrm{~mm}$. Joining of the comparatively thick walled GFRP and CFRP components can 
be supported by an infrared heating system, which plasticizes the matrix component efficiently within a short processing time.

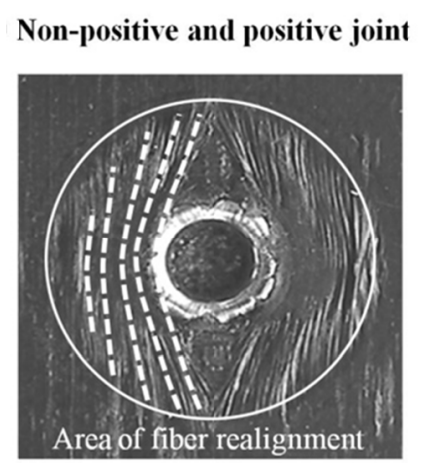

a)

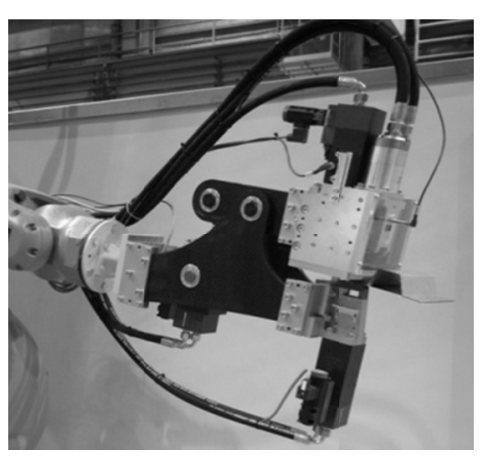

b)

Figure 2. Sample of a conventional Steel/GFRP $(1.5 \mathrm{~mm} / 3.0 \mathrm{~mm})$ FDJ joint and joining jig

For the investigations AlMg2.5/GFRP and FeP04/CFRP joints were performed. At all specimens, the phenomenon of realigned fibers could be detected visually around the closing head-side top layer of the FRP component. Due to the galvanic contact corrosion problem that occurs when carbon fibers and aluminum get in contact under presence of an electrolyte, the aluminum alloy was not joined with CFRP.

The applied joining point diameter of $5.3 \mathrm{~mm}$ was chosen, since most of the mechanical joints in actual body in white structures show similar geometric parameters. Table 3 summarizes the processing parameters and shows exemplarily samples of the manufactured FDJ joints.

Table 3. Manufactured FDJ joints

\begin{tabular}{cc}
\hline Tensile shear specimen & Processing parameters \\
\hline AlMg2.5/GFRP & Joining point diameter: $5.3 \mathrm{~mm}$ \\
& Joining force: $15 \mathrm{kN}$ \\
& Flow drill speed: $4500 / \mathrm{min}$ \\
\end{tabular}

FeP04/CFRP

(Number of specimens: 5)

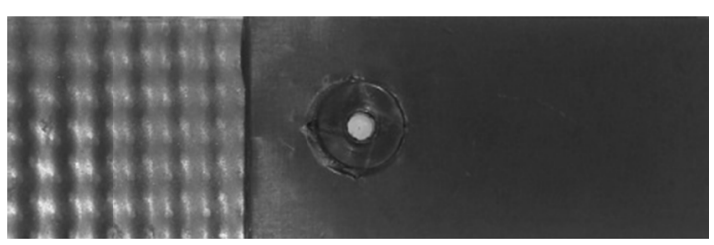

Joining point diameter: $5.3 \mathrm{~mm}$

Joining force: $20 \mathrm{kN}$

Flow drill speed: $3000 / \mathrm{min}$

Heating time: $14 \mathrm{~s}$

\subsection{Determination of the Tensile Strength Properties}

The performed specimens of table 3 were tested according to DIN EN ISO 14273. The determination of the tensile strength properties was carried out with the universal tensile testing machine UPM Zwick/Roell Z 250 (Figure 3). The pre-load was $10 \mathrm{~N}$. The span width was $100 \mathrm{~mm}$ and the test speed $2 \mathrm{~mm} / \mathrm{min}$ constant. 

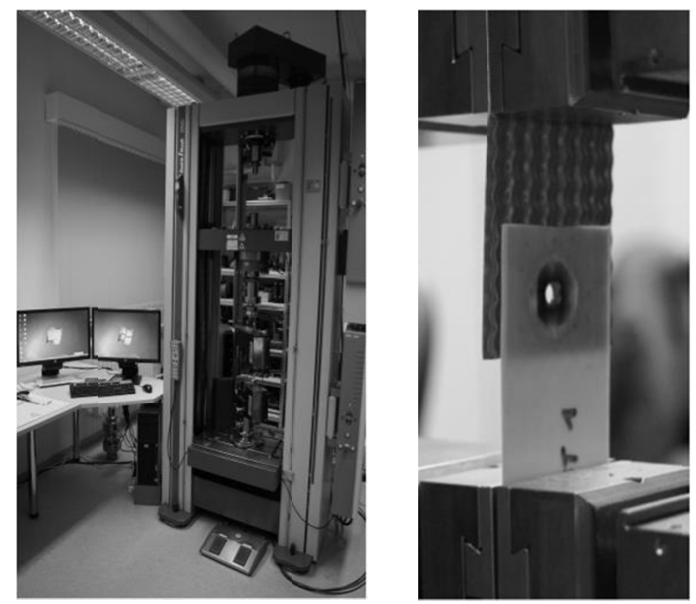

Figure 3. Determination of the tensile strength with the UPM Zwick/Roell Z 250

\subsection{Determination of the Fiber Arrangement at the Joint}

The determination of the fiber arrangement at the specimens occurred with the automatic incinerator "CEM Phoenix Standard Unit" (Figure 4). Because of the limited space inside the crucibles, cut outs were prepared and incinerated one hour at $650^{\circ} \mathrm{C}$ (according to DIN EN ISO 11667) under protective gas (nitrogen), to prevent the oxidation of the carbon fibers. Hereby the thermoplastic PA6 matrix was completely detached without any residues from the filaments, which remained afterwards loose and unbound at the metal component.
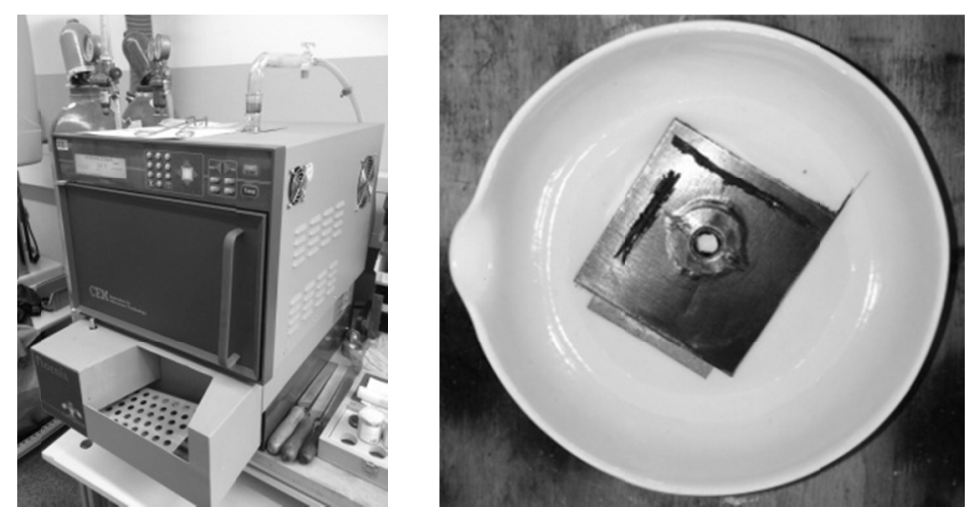

Figure 4. Automatic incinerator "CEM Phoenix Standard Unit" and CFRP specimen with crucibles

\section{Results}

\subsection{Static Tensile Shear Tests}
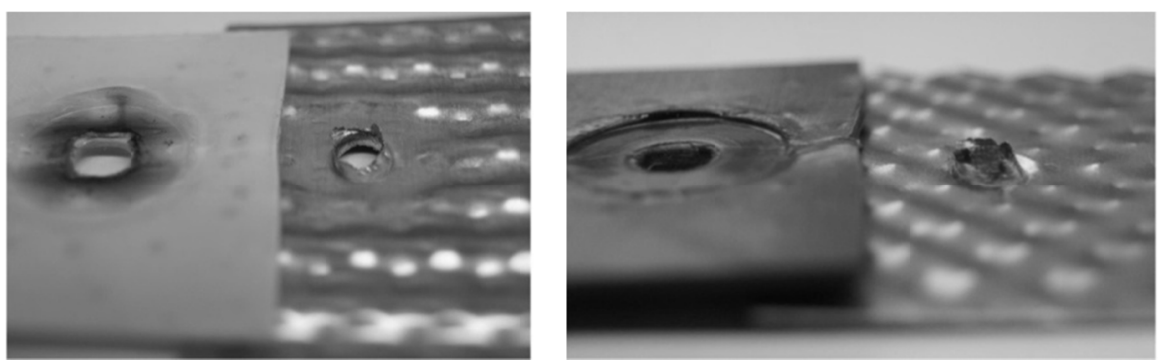

Figure 5. Damage of failed AlMg2.5/GFRP and FeP04/CFRP FDJ joints 
In the performed tensile-shear test all AlMg2.5/GFRP and FeP04/CFRP specimens fail in consequence of the high bearing stress, which occurs at the edge of the FRP-holes. The robustness of the joints is primarily - because of the considerably thinner wall thickness of the structured thin sheets - influenced by the metal components. The highly acting shear stresses at the joint induce finally bending up the closing head and consequently buckling of the remaining metallic bushing (Figure 5).

In particular the results of the strength tests confirm, that a high strength potential is achieved by the material combination FeP04/CFRP, with a determined tensile shear holding force of $644 \mathrm{~N}$ (Figure 6, black). In contrast to that, the values of the AlMg2.5/GFRP FDJ joints are about the half lower (Figure 6, grey). Furthermore it is to determine, that the stiffness of the joint is significantly lower. This is due to the - in comparison to FDJ joints with CFRP and steel - substantially lower young's modulus of GFRP and aluminum components (cf. Table 1 and 2 with Figure 6).
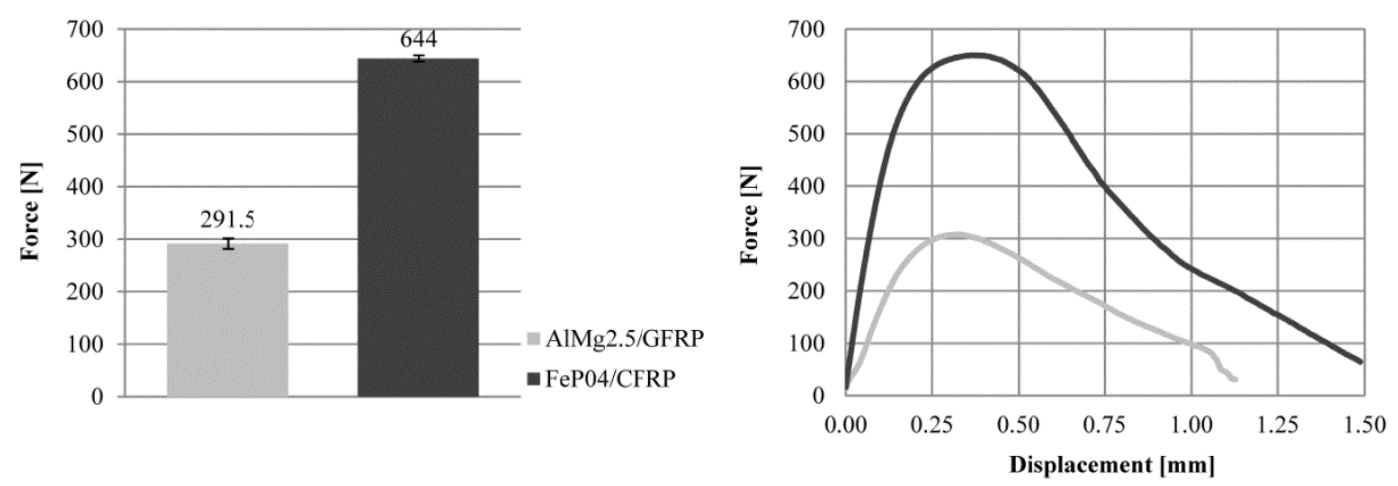

Figure 6. Tensile strength of structured AlMg2.5/GFRP and FeP04/CFRP FDJ joints and associated exemplary force/displacement curves

\subsection{Global In-Plane Fiber Alignment}

Unlike traditional technologies, the FDJ process is carried out from the metal side with heat assistance. With regard to the FRP components, this kind of process management is gentler on the material since fiber fracture (FF) is mostly avoided at top layers of the FRP components. Moreover it is shown that, due to the process-induced realignment in the region of the joining zone, the reinforcing fibers are not only appropriate for the force fluxes, but also have a higher fiber volume content - similar to construction principles in nature (for example at knotholes). In the area of the joining point, high fiber content is achieved due to the radial dispelling of fibers during the shaping of the bushing and to the formation of the closing head with the forming tool (Figure 7).

a)

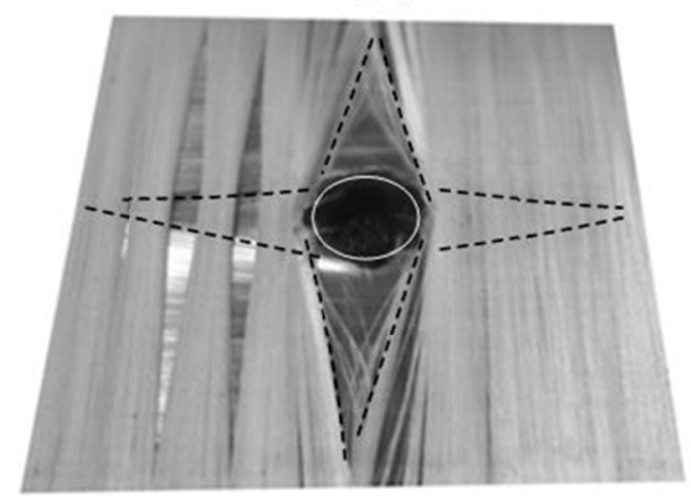

b)

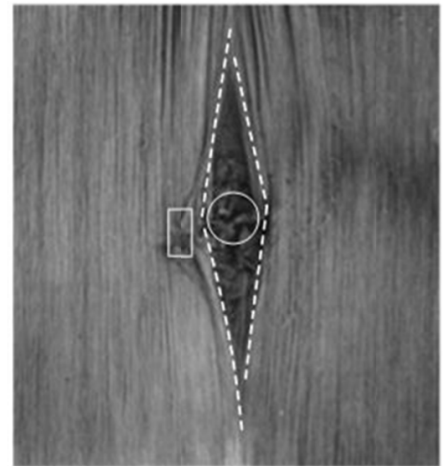

--- Realigned fibers

Joining point

Fiber fracture $(\mathrm{FF})$

Figure 7. Realigned fibers after incineration of PA6 matrix at top layers of AlMg2.5/GFRP (a) and FeP04/CFRP (b) specimens 
In comparison to the top plies of inner UD layers of AlMg2.5/GFRP and FeP04/CFRP flow drill joints, the amount of fiber fractures is increased at inside lying fiber plies (Figure 8).
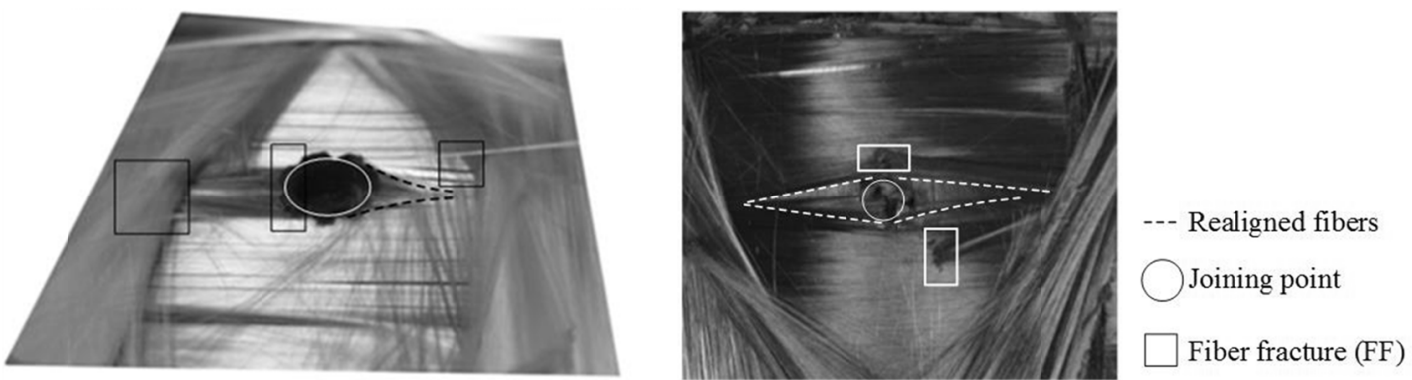

Figure 8. Increased amount of FF at inner (third) fiber layers of AlMg2.5/GFRP and FeP04/CFRP FDJ joints

Fiber fractures are usually induced by the formed bushing. Unlike the closing head-sided UD layers, which will be first pierced in the later course of the process by the rotating mandrel and, thus, will be expanded continuously, the UD layers at the metal sheet get in contact for the first time primarily with the formed bushing. Once the mandrel pierces the metal sheet, a sharp-edged bushing is formed. However, at this time, the mandrel is situated within the bushing and, therefore, does not contribute to a steady realignment of all fibers in the joining zone. With that, fibers are partially cut by the sharp edges of the formed bushing until the mandrel - with increasing load adjusted realignment fibers - completely penetrates the FRP component.

\section{Discussion}

The Flow drill joining process constitutes a new type of technology for joining sheet metals and FRP components on a thermoplastic basis in a way appropriate for the force fluxes. During the FDJ process, a bushing is shaped from the metallic base material with the aid of a rotating mandrel. In this respect, the metallic component is plasticized locally. Due to the contact heating, the FRP component is melted locally at the same time. While the bushing is being shaped by the plastic, the then moveable fibers are deviated around the imperfection in a way appropriate for the force fluxes. Due to the final defined forming of the bushing, the joining members are joined with each other in both positive-locking and non positive-locking forms. Moreover, the FDJ joint can provide a defect-tolerant force introduction system for multi-material high-performance structures, which can be subjected to high loads for applications in large-scale series technology.

The applicability of the FDJ process was positively evaluated for multi-material joints with extremely thin walled and structured metal sheets. It could be demonstrated that the specific realignment of fibers - in spite of the strongly different wall thicknesses of the joining partners - could be realized at the investigated material pairings AlMg2.5/GFRP and FeP04/CFRP. The realignment of fibers was confirmed visually at top layers and by incinerating the polyamide 6 matrix system, wherein the FRP joint could be analyzed with respect to fiber fracture (FF). In particular these kinds of failures mostly occur process-related at inner layers of the FRP components.

Through the load and material adapted design of the joints, high tensile shear strengths were determined at FeP04/CFRP specimens. Against the background of the small standard deviation at both experimental series, it can be stated that the FDJ joining process works sufficiently and stabile. Furthermore, as a consequence of the considerably lower required joining forces against conventional techniques, the structures of the patterns are almost unimpaired. Thus, the high bending stiffness properties of the structured metal thin sheets remains in a FDJ based multi-material construction with thermoplastic FRP. As part of the investigations it was demonstrated that a high benefit in weight reduction can be achieved, when applying the suggested lightweight design approach.

\section{Acknowledgement}

This work was performed within the Federal Cluster of Excellence EXC 1075 "MERGE Technologies for Multifunctional Lightweight Structures" and supported by the German Research Foundation (DFG). Financial support is gratefully acknowledged.

The publication costs of this article were funded by the German Research Foundation/DFG (Geschäftszeichen INST 270/219-1) and the Chemnitz University of Technology in the funding programme Open Access Publishing.

\section{References}

Collins, M. W., \& Brebbia, C. A. (2006). Design and Nature II: Comparing Design in Nature with Science and Engineering (6th ed.). Southampton: WIT Press. 
Döhler, C., Hälsig, A., Podlesak, H., Czech, A., Nestler, D., Wielage, B., ... Kroll, L. (2014). Energy-Efficient Joining Technologies to Realise Dissimilar Joints of Metal and Fibre-Reinforced Plastics. In R. Neugebauer \& W. G. Drossel (Ed.), 3rd ICMC 2014 - International Chemnitz Manufacturing Colloquium/3rd International Colloquium of the Cluster of Excellence eniPROD Part 1 Innovations of Sustainable Production for Green Mobility. (Vol. 80, pp. 447 - 459). Chemnitz, Germany: Fraunhofer-Institut für Werkzeugmaschinen und Umformtechnik IWU.

Goede, M., Stehlin, M., Rafflenbeul, L., Kopp, G., \& Beeh, E. (2009). Super Light Car-lightweight construction thanks to a multi-material design and function integration. European Transport Research Review, 1, 5-10. http://dx.doi.org/10.1007/s12544-008-0001-2

Ind.Exp. (2013). Carbon Fibers \& Carbon Reinforced Plastics (CFRP) - A Global Market Overview. London: Industry Experts.

Klein, B. (1997). Leichtbaukonstruktion (3rd ed.). Braunschweig, Wiesbaden: Vieweg.

Kroll, L. (2009). Textilverstärkte Kunststoffbauteile in funktionsintegrierender Leichtbauweise. In: E. Wintermantel, S.-W. Ha (Ed.), Medizintechnik: Life Science Engineering (Vol. 5, pp. 343 - 356). Berlin Heidelberg, Germany: Springer.

Malikova, V., Ossenbrink, R., Viehweger, B., \& V. Michailov (2013). Experimental study of the change of stiffness properties during deep drawing of structured sheet metal. Journal of Materials Processing Technology, 11, 1811 - 1817. http://dx.doi.org/doi:10.1016/j.jmatprotec.2013.05.005

Rosato, D. V. (2005). Reinforced Plastics Handbook (3rd ed.). Oxford: Elsevier Advanced Technology

Rotheiser, J. (2009). Joining of Plastics-Handbook for Designers and Engineers (3rd ed.). Munich: Carl Hanser Verlag.

Schürmann, H. (2005). Konstruieren mit Faser-Kunststoff-Verbunden (2nd ed.). Berlin, Heidelberg: Springer-Verlag.

Seidlitz, H. (2013). Entwicklung von kraftflussgerechten Verbindungstechniken für Mischbauweisen mit thermoplastischen Faserverbunden und Metallen. Munich: Verlag Dr. Hut.

Seidlitz, H., Kroll, L., \& Ulke, L. (2009). Load adjusted joining technology for Composite-Metal Hybrids. In T. Burczyński, W. Cholewa, \& W. Moczulski (Ed.), Methods of Artificial Intelligence. (pp. 51-52). Gliwice, Poland: Silesian University of Technology. Faculty of Mechanical Engineering. Department of Fundamentals of Machinery Design.

Seidlitz, H., Ulke, L., \& Kroll, L. (2013). DE 102009013265B4: Methods and tools for producing a mixed module. Chemnitz University of Technology.

Seidlitz, H., Ulke-Winter, L., \& Kroll, L. (2011). Herstellung hochbelasteter Leichtbaustrukturen in Mischbauweise. In: B. Wielage (Ed.), Tagungsband zum 18. Symposium Verbundwerkstoffe und Werkstoffverbunde (Vol. 41, pp. 360 - 365). Chemnitz, Germany: Eigenverl.

Simon, S. (2005). Werkstoffgerechtes Konstruieren und Gestalten mit metallischen Werkstoffen. Cottbus: Brandenburgische Technische Universität Cottbus.

Sterzing, A. (2005). Bleche mit Wölbstruktur: Wie praxistauglich sind sie? Blech in Form (2005)3, 28-31.

Viehweger, B., Simon, S., \& Hoppe M. (2005). Strukturierte Feinbleche - Umformverhalten bei Zieh- und Hydroformverfahren, Konstruktion: Zeitschrift für Produktentwicklung und Ingenieur-Werkstoffe, 57(5), 7-9.

Viehweger, B., Simon, S., Wagner, L., \& Berg, A. (2002). Aluminium - Stahl - Verbundblech. In VDI-Gesellschaft Fahrzeug- und Verkehrstechnik, Entwicklungen im Karosseriebau - Development in Chassis Engineering (VDI-Berichte Nr. 1674). (pp. 377 - 384). Düsseldorf, Germany: Verein Deutscher Ingenieure Verlag.

Witten, E. (2013). Composites-Marktbericht 2013. Frankfurt am Main: AVK - Industrievereinigung Verstärkte Kunststoffe e.V.

\section{Copyrights}

Copyright for this article is retained by the author(s), with first publication rights granted to the journal.

This is an open-access article distributed under the terms and conditions of the Creative Commons Attribution license (http://creativecommons.org/licenses/by/3.0/). 